\title{
O EXTREMISMO ISLÂMICO - SUA PUJANÇA E SUAS DEBILIDADES ${ }^{1}$ ISLAMIC EXTREMISM - ITS STRENGTH AND ITS DEBILITY
}

\author{
Bouzid Izerrougene ${ }^{2}$
}

\begin{abstract}
Resumo. Buscamos entender a origem do extremismo islâmico, suas potências e suas fraquezas, em vistas a encontrar formas para sua atenuação, valendo-nos dos parâmetros civilizacionais do mundo muçulmano, dentro da sua história interna e da sua complexa relação com a civilização ocidental.

Palavras chave: extremismo islâmico, Daesh,
\end{abstract} identidade, alteridade, globalização.
Abstract. We seek to understand the origin, strengths and weaknesses of Islamic extremism and to propose ways for its attenuation, relying on the civilizational parameters of the Muslim world, within its internal history and its complex relationship with western civilization.

Key words: Islamic extremism, Isis, identity, otherness, globalization.

E desde então, sou porque tu és. E desde então és sou e somos... E por amor, serei... Serás...Seremos... Pablo Neruda

\section{Introdução}

Tentaremos entender a razão de ser do extremismo islâmico e propor formas para o seu combate. Para tanto, precisamos conhecer os parâmetros civilizacionais do mundo muçulmano, dentro da sua história interna e da sua complexa relação com a civilização ocidental. Faremos, numa primeira seção, uma breve exposição da história do mundo muçulmano, ressaltando o processo em que se deu a divisão entre os xiitas e os sunitas e a formação das organizações estatais contemporâneas. Em seguida, discutiremos o fenômeno Estado Islâmico, sua formação, sua ideologia, atratividade e ambições. Tentaremos mostrar, nessa segunda seção, que a religião para os jihadistas extremistas é antes um meio de ascensão que objeto de uma fé. Admitimos que a focalização do extremismo islâmico na religião e não em outro suporte vem do fato de que as sociedades muçulmanas estão ainda pouco secularizadas e nelas a consciência coletiva não se libertou do peso da religião, a qual permanece como único meio portador de sentido. Assim, os conflitos de ordem geopolítica permanecem ocultados em formulações confissionais que acabam por obscurecer a própria religião e perpetuar os conflitos.

\footnotetext{
${ }^{1}$ Esse texto é resultado de três palestras proferidas entre 2015 e 2016 para os grupos de estudos Primo e Cajuvi, em Salvador, Bahia. 0 autor agradece ao amigo André Ghirard e aos pareceristas anônimos da revista Malala, cujos comentários e recomendações melhoraram o trabalho.

${ }^{2}$ Natural da Argélia, doutor em economia pela Universidade Paris XIII, professor titular da Universidade Federal da Bahia. CV Lattes: http://buscatextual.cnpq.br/buscatextual/visualizacv.do?id=K4783038E7. Email: bouzid@ufba.br
} 
Sem ignorar as tensões e distorções contemporâneas, produtos da colonização e das ditaturas nacionais que, todas, obstruíram o caminho da modernização social, tentaremos, no final, entender a violência do radicalismo islâmico como, fundamentalmente, o resultado de uma crise de identidade. A crise de identidade está no sentimento dos muçulmanos de estarem, há séculos, espoliados, dominados e menosprezados. Os fundamentalistas exploram esse sentimento e enfatizam o carater hegemônico do Ocidente e a ameaça que representa. Hoje, a globalização acelerada provoca uma maior necessidade de afirmação identitária e gera, em razão da angústia existencial que acompanha a pressão das bruscas transformações materiais e tecnológicas, uma carência em valores espirituais que os extremistas souberam canalisar. Eles, sob o pretexto de defender a identidade da ameaça ocidental, rechaçam qualquer visão modenista e pregam o confinamento no rancor e na brutalidade. Minar o obscurentismo dos fanáticos sanguinários e solapar sua legitimação nos tecidos sociais são duas atitudes que passam pelo desvelamento de suas ambições políticas, assim como da sua narrativa arcaica e sectária. Importa ressaltar que na sua violência suicida os fanáticos condenam o mundo muçulmano a mais declínio e mais atraso $^{3}$. Urge nas sociedades muçulmanas superar o dilema segundo o qual a modernização lhes implica necessariamente ficar à mercê da cultura ocidental e perder a identidade, entendendo que tal dilema está deixando de ser pertinente, pois a modernidade hoje se tornou universal e não é mais privilégio exclusivo do Ocidente.

Nessa universalidade, os diferentes povos que se sentem marginalizados no mundo moderno podem passar a viver a modernidade e não a sentir como fenômeno exógeno, imposto. Nela, a globalização pode se afirmar como processo enriquecedor de mesclagem e de integração de todos, atenuando o seu aspecto uniformizador, empobrecedor e contestável. Abre-se caminho para estender a todo humano um valor intrínseco, restituindo a todos a possibilidade de serem diferentes sem serem desiguais.

\section{A formação do mundo muçulmano, a cisão sunita/xiita e a ascensão do fundamentalismo - breve relato histórico.}

O Islã nasceu na península arábica na virada do século VI para o século VII e, cem anos depois, aproveitando o vazio geopolítico que seguiu ao declínio do império romano, espalhou-se com extraordinária rapidez. Em poucas dezenas de anos, um punhado de beduínos da Arábia, à margem da história até então, tornou-se senhor de vastos territórios, que se estendem da Espanha até o extremo da Ásia, passando por grandes áreas da África. Tudo foi feito de forma surpreendentemente ordenada e relativamente respeitosa das culturas e religiões dos povos conquistados.

\footnotetext{
${ }^{3}$ No seu livro Jihad, publicada em 2000, Gilles Kepel estuda o desenrolar do Islã político, observa que a radicalização é antes um sinal de declínio do que de força, concluindo que o islamismo não tem mais capacidades para "mobilizar utopias".
} 
A força da espada teve certamente seu papel nas conquistas, que não eram marchas pacíficas, mas, considerando o escasso exército árabe em relação à imensidão dos territórios e ao grande número de povos submetidos, pode-se admitir a importância da persuasão doutrinária, mítica e religiosa do Islã. Soma-se a isso a habilidade dos mercadores árabes em ganhar a simpatia dos povos por onde transitavam com suas caravanas.

No ano de 570 nasceu Maomé que começou a pregar publicamente aos 33 anos de idade, conquistando a cidade de Madina e, depois, a Meca, ambas na atual Arábia Saudita. Em 632 morre sem deixar orientação para sua sucessão. Os sucessores são os Califas, ditos Arachiddun, isto é, os bem guiados. Embora a lenda os magnifique, os companheiros de Maomé brigaram ferozmente sob o manto da religião pelo poder, e suas batalhas fratricidas fizeram muitas vitimas. Na história da civilização islâmica, os conflitos políticos costumam ser dissimulados em pretextos religiosos que alimentam o sectarismo, enraizam a violência e perpetuam o atraso. Analisando essa tendência, Ashmawy, afirma que:

Chaque secte prétendait au monopole de la vérité et de la foi sincère, accusant les autres d'être dans l'erreur et de renier Dieu et la religion. Dans les divisions qui s'ensuivirent, les valeurs et les idéaux du Coran s'éclipsèrent sous le discrédit et la falsification, et les musulmans en revinrent aux mœurs antéislamiques (Ashmawy, 1998: 56).

Houve, no total, quatro Califas reconhecidos formalmente como guias de todos os muçulmanos. Mas a unificação começou a roer no reinado do último Califa, Ali Bin Abi Taleb (chamado Imam Ali), que, na opinião de muitos muçulmanos, o profeta Maomé o teria desejado como seu primeiro sucessor. Ali chegou ao Califado suspeito de ter comandado a morte do seu antecessor, Othman Ibn Affane, e perdeu a adesão da maioria dos correlegionários. Os contestadores exigiram a entrega dos assassinos de Othman e organizaram uma ferrenha aposição que culminou na guerra civil, entre 656 e 657, em Bassurah e Al Raqqa (Bassioni, 2012), onde os combatantes de cada campo pertenciam às mesmas tribos, mesmas famílias e mesmos clãs. Imam Ali ganhou a guerra, mas não conseguiu manter o controle sobre o País do Sham (atual Síria, Libano mais a Jordânia\}, que se tornou área dissidente, sob o comando do Muawiya, o lider que fundou a dinastia dos Omíadas em 661, com sede em Danasco.

Com a hegemonia dos Omíadas, o centro do poder no mundo muçulmano se deslocou da Arábia para o Sham e os partidários de Ali se tornaram minoria, passando a sofrer severas perseguições. Partidário em árabe se disse xiaat, daí o nome xiita para diferenciar os seguidores de Ali da maioria muçulmana formada por sunitas. Operou-se uma cisão histórica, cuja formulação confecional irá perpetuar a ocultação do carater político dos conflitos entre muçulmanos. 
Ali não soube colocar os interesses tribais e familiares acima do dogma e da transcendência da religião, e perdeu por Muawiya, que, ele, apostou na persuação política e na força das armas (Puri, 1924). Em torno da personalidade do Califa Ali e da narrativa do heroismo na resistência de seus filhos contra Damasco se formou o ramo xiita, com certa exaltação religiosa diferente dos demais muçulmanos sunitas. As crenças sunita e xiita derivam da mesma fonte: a Suna, que é o conjunto do Corão e do Hadith (falas de Maomé). Essa mesma fonte autoriza, contudo, divergências teológicas e jurídicas entre as escolas. Os xiitas dão continuidade na sucessão de Maomé através dos Imames, que são guias espirituais e guardiãos da Sharia. A Sharia é um conjunto de leis inspiradas no Corão e que ditam o comportamento dos muçulmanos. Depois do segundo filho de Ali, terceiro Imam, vieram mais nove outros Imames. O décimo morreu aos cinco anos de idade e espera-se o seu retorno: o messia que, segundo a crença xiita, regressaria com Jesus Cristo ${ }^{4}$ e estaria guiando até hoje os xiitas de forma oculta.

Os Omíadas dominavam a parte sunita do mundo árabe, enquanto isso a dinastia dos Fatimitas governava os povos xiitas, menos o Iraque, onde nasceu, em 762, o Califado dos Abássidas, cujo poder não tardou a superar a hegemomia de Damasco. A disputa entre os Califados ocorria basicamente em torno de territórios dominados. Em 929, os Omíadas fundaram o Califado de Cordoba, na Espanha, na mesma época em que os xiitas Fatimitas se introduziram na África do Norte e dominaram os territórios que correspondem hoje a Argélia e Tunisia. Foram logo expulsos e se estabeleceram no Egito, fundando o Califado do Cairo, onde construiram a famosa universidade islâmica do El Azhar.

Diante da expansão da influência xiita na África do Norte (incluindo o Egito), os sunitas recorreram, mais uma vez, a motivos dogmático para incriminar os xiitas, quando denunciaram o que era na sua opinão desvios de interpretação cometidos pelos seguidores de Ali. Reiteraram que a única voz da sabedoria estava na Suna tal como foi transmetida por Maomé, apoiando-se nas obras do famoso teólogo El Ghazali (10581111). El Ghazali se insurgiu contra a filosofia aristótelica que teólogos xiitas começaram a introduzir no Islã, a exemplo do que fez a Igreja católica. Os sunitas também nessa época reprimiam o sufismo que, embora sunita, era suspeito porque parece com a contemplação dos cristãos e apresenta pontos comuns com o xiismo. Expulsaram os xiitas do Egito em 1171 através do exército de Salah Al Dine El Ayyubi, Saladino, o curdo que liderou a oposição aos cruzados. Em seguida, Al Azhar foi arrancada dos xiitas e se tornou um polo de doutrina sunita.

Enquanto os xiitas admitem interpretação e adaptação dos textos sagrados, os sunitas consideram o dogma, que é a própria Suna, fixo e imutável ${ }^{5}$. Sunitas e xiitas

\footnotetext{
${ }^{4}$ Há uma grande aproximação dos cristãos no xiismo, sincretismo que os sunitas extremistas não perdoam. ${ }^{5}$ A linha xiita é mais renovadora. Os xiitas se esforçam em adaptar a Suna, o que lhes autorizou, no Irã, estabelecer um poder constitucionalista, que chegou a condenar e enforcar religiosos; instalar o regime dos xás e abrir espaço à revolução islámica de Khomeini em 1979. Hoje, o Irã é o país menos instável e inseguro do mundo muçulmano, onde há mais Estado de Direito. Prevaleceu no Ocidente a ideia de que os xiitas
} 
divergem por muitos outros motivos que podem ser considerados triviais, como por exemplo a aparência física de Deus, os rituais, o casamento, as datas comemorativas, etc. Na verdade, os dois ramos não formam entidades homogêneas, mas são feitos de grupos bastante diversos.

Os xiitas se dividem em ismailitas, que surgiram a partir de 762 na Síria e no Iraque; druzes, que apareceram a partir do ano 1000, na Síria e no Libano; alauitas, também na Síria, a partir de 884; azeris, no Azerbeijão e na Turquia; hazaras, no Afeganistão, etc. No Irã dominava a doutrina sunita até 1501, imposta até então pela dinastia dos Safávidas (azeris e curdos), via sufismo (Shuster, 2007). Atualmente, fora o Irã, Bahrein e Iraque, onde representam, respectivamente $96 \%, 70 \%$ e $60 \%$ das populaçoes locais, os xiitas são minoria em todos os países muçulmanos; representam cerca de $10 \%$ do total (PewForum, 2009).

Quanto à corrente da maioria sunita, ela permanece desde o século XI dividida em quatro escolas: malaquita na África do Norte, Egito e Sudão; xafiita, no Egito, Indonésia, Malasia e Iêmen; hanafita, no Iraque, Síria, Irã, Turquia, China, Paquistao, India, Bengladesh e nos Bálticos (Bosnia, Albania, Macedónia); e, hanbalita, na Península Arábica.

A partir dos meados do século XIII, a civilização árabe-muçulmana começou a desmoronar. 0 primeiro grande golpe foi dado pelos mongois que invadiram Bagdá em 1258 e colocaram um fim na dinastia Abbássida. Em 1492 foi a vez da queda do reino de Granada. Em 1517, o imperador otomano proclamou-se Califa de todos os muçulmanos. Sob o domínio dos turcos, a expansão muçulmana se limitou ao Azerbeijão e a uma pequena parte limítrofe da Georgia (Black, 2001). A Letargia tomou conta do mundo muçulmano que experimentou sua «Idade Média» naquele período.

O Império Otomano (1299-1922) dominou todo o mundo árabe, menos a região central da Península Arábica. Nessa área, berço do Islã, se encontram as cidades sagradas de Meca e Madina, cuja relevância para os pelegrinos alimentava rivalidades tribais e concedia a seus controladores considerável influência e importante fonte de renda. Em 1744, uma tribo vencedora, cujo chefe, Muhammad Ibn Saud, uniu-se a um influente religioso fundamentalista do Islã, Muhammed Abd Al-Wahab (1703-1792), para criar o Reino Saudita. Quase dois séculos depois, em 1915, em plena Primeira Grande Guerra, a aliança militar da família Saud com a Inglaterra e contra os turcos (aliados da Alemanha) permitiu a ampliação territorial do reinado e sua formação em Estado-nação. A anexação de territórios pela dinastia de El Saud continuou até 1932. Em 1938, a descoberta de petróleo permitiu estender a influência do reinado e da sua conservadora doutrina wahabita para além da Península, combatendo, com comprovada cumplicidade do Ocidente, toda tentativa de autonomia e de modernização no mundo muçulmano (Belaali, 2012). 
Depois da queda do Império Otomano, os territórios do Oriente Médio foram submetidos aos protetorados britânico e francês e só obtiveram sua independência durante ou depois da segunda guerra mundial. Ocorreram, então, dois grandes movimentos no mundo muçulmano: a modernização da Turquia, relativamente sucedida, sob o comando de Mustafa Kamel Ataturk, e o movimento panarábico que buscava a unificação do mundo árabe em um único Estado. Este movimento chegou ao poder no início da década de 1960 no Egito através do nacionalismo republicano de Nasser e, na Síria e no Iraque, através do partido baasista nacionalista e socialista. 0 panarabismo conseguiu acalmar os conflitos confessionais graças à promessa de unificar todos os árabes e, também, devido à sua estratégia de apontar o inimigo externo. Mas, no final, seus protagonistas se transformaram em ditadores.

A Arábia Saudita, aliada do Ocidente e rica como se tornou, persistiu em contrariar os movimentos nacionalistas, vistos como aliados da URSS naquele contexto de guerra fria. A oposição começou a tomar consistência através de movimentos religiosos radicais nos paises sunitas, como a Irmandade Muçulmana no Egito e na Síria, infleunciados e apoiados pelo wahabismo saudita. 0 wahabismo é uma tendência rigorista do Islã que prega a volta aos fundamentos, desprezando os diferentes dogmas ou doutrinas. Essa corrente estima que o Islã foi adulterado, o que justificaria uma reforma ortodoxa, uma ortodopraxia (ortodoxia na ação). Sunita na essência, defende o imobilismo no pensamento e vê qualquer inovação como heresia, o pior dos males. Tem como meta, desde que nasceu em Madina, nos meados do século XVIII, a dominação do mundo muçulmano. Foi reativada pela dinastia de Al Saud a partir dos anos 1950 e 1960.

Na década de 1960, a Arábia liderava o movimento do panislamismo para impedir a expansão daquele panarabismo iniciado no Egito e no Iraque, assim como enfraquecer a influência dos xiitas na região. Em suas ações contra os panarabismo, a monarquia dos xarifados fomentou revoltas e não hesitou a armar seus próprios inimigos xiitas contra nacionalistas sunitas, mostrando como os conflitos podem não ter nenhum motivo confecional, como no caso da guerra do Iêmen.

Até 1960, o Iêmen era governado pelos xiitas (que são um terço da população), quando o nacionalista egípsio Nasser, interessado em controlar o mar vermelho, provocou uma revolução republicana sunita. Apesar de rejeitar todos os seguidores de Ali, Arábia Saudita incitou os conservadores xiitas contra Nasser, numa guerra que acabou por dividir o país, em 1967. A reunificação veio a acontecer em 1990. Abdullah, sunita, governou por mais de 30 anos, com apoio da Arábia Saudita ${ }^{6}$, oprimindo e desprezando os xiitas locais, conhecidos como hutis ou zaidistas. Estão sendo a toda hora bombardeados pelas forças militares de um tal de Conselho de Cooperação dos Estados Árabes do Golfo, formado por Omã, Emirados Árabes Unidos, Arábia Saudita, Qatar, Bahrein e Kuwait.

\footnotetext{
${ }^{6} \mathrm{O}$ Iêmen é uma das saídas do petróleo saudita.
} 
Sempre na busca de maior influência no mundo muçulmano, o reino dos Ibn Saud concluiu, em 1961, a Universidade Islâmica de Madina, onde passaram a se reunir os maiores teólogos do Islã sunita. Madina recebeu e financiou um grande número de estudantes de todos as partes, preparando-os a pregar o wahabismo em seus países de origem. A doutrina encontrou e ainda encontra terrenos fértis nos países árabes, em razão, essencialmente, das crises dos projetos nacionalistas que se tornaram ditaduras corrumpidas.

Na década de 1980, com apoio dos EUA, a Arábia patrocinou Saddam Hussein na sua guerra contra Irã, visando enfraquecer a influência da revolução iraniana na região. Era uma guerra para o controle do Golfo Pérsico, por onde transitavam cerca de 65\% do petróleo exportado. Não era, portanto, um conflito de ordem apenas confessional, era antes de ordem geopolítica, como em quase todos os litígios entre os muçulmanos. Fez um milhão de mortos e parou em 1988 sem vencedor nem vencido. Acabou, todavia, por fortalecer os seguidores de Ali em geral e por despertar os sentimentos de opressão e o desejo de justiça nas populações xiitas do Iraque, Iêmen, Bahrein e da própria Arábia. A diabolização do Irã se revelou um grande erro.

Em 1979, enquanto o xá do Irã era removido e se instalava a República Islâmica naquele país, a invasão do Afeganistão pelo exército vermelho irá dar um impulso extraordinário ao radicalismo sunita. Arabia Saudita, com ajuda dos EUA, recrutou combatentes em todos os países muçulmanos, os chamados jihadistas internacionais ou internacionalistas, para expulsar os soviéticos do Afeganestão, favorecendo a organização Al-Qaeda, que nasceu naquele contexto.

No Afeganistão, a etnia sunita dominante dos pashtuns, aproveitando a guerra contra os soviéticos, realizou um verdadeiro genocídio dos xiitas Hazaras ${ }^{7}$. Com a expulsão dos sovieticos, os talibãs, também sunitas, passaram a controlar o Afegastão e a aplicar a Sharia, reprimindo e assassinando milhares de seus conterrâneos (Gier, 2016).

No Afeganestão, os combatentes internacionalistas adotaram a doutrina salafista, em substituição ao wahabismo. Encontraram no salafismo uma formulação religiosa que melhor atende às suas pretensões políticas, que mais excita o sentimento de ser dono da verdade e da fé sincera e que dá o direiro de considerar heréticos todos aqueles que não pensam igual a eles e de encarregar-se de combatê-los até a morte.

O salafismo tem suas origens na doutrina hanbalita, formulada na Península Arábica por Ahmed Ibn Hanbal no século IX. Do hanbalismo surgiram duas principais referências ideológicas, que são a de Ibn Taymiya, no final do século XIII, e aquela do wahabismo, no século XVIII, promovida por Mohamed Ibn Abdelwahab. No início do

\footnotetext{
${ }^{7} 0$ mesmo ocorre no Paquistão.
} 
século XX, o pensamento salafista foi reformado e modelado em projeto político pela confraria egípcia fundamentalista da Irmandade Muçulmana, fundada em 1928 por Hasan al-Banna (Amghar, 2011).

O salafismo adotado pelos internacionalistas do Afeganistão a partir do final do século XX se assemelha, na verdade, ao wahabismo na sua vertente mais conservadora e radical. A principal divergência está basicamente na dimensão almejada de poder: enquanto os wahabitas se contentam com um poder local, os salafistas sonham com o grande Califado de todos os muçulmanos (L'Express, 2003).

Depois que os sovieticos foram expulsos, os internacionalistas voltaram para seus países de origem e, apoiados na doutrina salafista e no dinheiro das monarquias do Golfo, declararam guerra a praticamente o mundo inteiro: aos govenos populistas que ainda reinavam no mundo árabe, às nações ocidentais elegidas como inimigas viscerais, às populações africanas, vistas como pagãs, etc. Estão em muitos territórios a semear o terror: no Egito, na Líbia, Iêmen, Bahrem, Nigeria, Mali, Sudão, Argélia, Tunísia, Niger, Tcahde, Iraque, Síria, Turquia, alem dos paises ocidentais. Têm grande presença no Iraque e na Siria, onde recusam o poder da maioria xiita, ocupam vastos territórios e proclamam Estado autonomo, o Estado Islâmico: o Daesh.

\section{0 Daesh e sua razão de ser}

O Estado Islâmico é chamado por seus protagonistas de Dawlah Islāmiyya fi-l-'Irāq wa-alShām - Daesh. Literalmente: Estado Islâmico no Iraque e no Levante. 0 Levante é o Sham, que representa o Maxerreque (o Oriente Árabe) menos o Iraque. Fala-se do Sham também como a Grande Síria, que inclui Síria, Jordânia, Líbano e Palestina ${ }^{8}$. O Estado Islâmico (EI), conhecido em inglês como ISIS, não possui, de verdade, nenhum estatuto jurídicopolítico de Estado, nem, tampouco, a legitimidade para pretender representar a todos os muçulmanos. É uma organização terrorista militar e política de ideologia salafista jihadista que surgiu em 2006, em territórios do Iraque. Mais tarde, em junho de 2014, depois que incluiu grande área e diversas cidades da Síria, proclamou-se Daesh. A desestabilização geopolítica causada pelas guerras nestes países facilitou a sua rápida expansão, acendendo nele a ideia megalomaníaca de formar-se em Califado e dominar, senão todos os muçulmanos, todos os sunitas (Mills, 2016).

O Daesh foi formado pela associação de atores de diversas origens: terroristas de AlQaeda, militares do regime de Saddam, jihadistas "internacionalistas" do Afeganistão, alguns rebeldes opostos a Bachar Al Assad e, ainda, outros mercenários, bandidos ou mafiosos, fora da lei. Todos se valem da ideologia salafista ultraconservadora, purista e violenta, que se apega aos princípios de um Islã medieval e que impõe a aplicação totalitarista da

\footnotetext{
${ }^{8}$ Tantos povos arrolados no suposto Estado Islâmico se que fossem sequer consultados.
} 
Sharia. Seus adeptos, fundamentalistas messiânicos, politizam e instrumentalizam a religião, sonham com o retorno de uma época onde existiam os Califas (século VII) e visam a implantação de um Estado teológico. Inventam a seu gosto leis repressoras e retrógradas para completar o acervo jurídico da Sharia, na base de deliberações extemporâneas e interpretações devaneadoras dos textos sagrados, conforme seus interesses imediatos de poder. Eles admitem que se matem pessoas que não seguem o seu fundamentalismo corânico. São intolerantes e perseguem todos aqueles que pensam diferente, particularmente os correligionários, como os xiitas, sufistas, drusos, alauitas, etc.

A sua marca principal tem sido o terror que já levou à perda de centenas de milhares de vidas. Transformam em pecado todo tipo de expressão artística e corporal (música, dança, pintura, escultura, etc.), proíbem os cantos e as comemorações, mesmo aqueles do calendário islâmico. Eles cerceiam particularmente a mulher e impõem para todos os gêneros formas de se vestir, de saudar, se comportar em público e no lar. Fundamentalizam os costumes e se intrometam com violência em todos os campos de vida, privada e pública, configurando assim um verdadeiro regime teológico-fascista-militar.

Curiosamente, os jihadistas salafistas não aplicam a Sharia para orientar suas próprias condutas. Eles se autorizam a todas as heresias, maculando a religião muçulmana e atirando a maldição do mundo sobre os muçulmanos. Praticam atividades criminosas, assassinato de oponentes e de civis, tráfico humano, de drogas e de armas. Podem espoliar, sequestrar, saquear, estuprar, ceifar vidas aos montes e sem discriminação, fazendo tudo em nome de Deus. Pretendem conhecer o caráter e os desejos que eles humanizam do Alá e castigam tudo que consideram ou podem vir a considerar ofensa ao seu Deus imaginário. São niilistas, doentes de si, megalomaníacos que semeiam a morte por conta de um Divino impiedoso, raivoso e vingativo, a quem eles, na verdade, ímpios, pretendem substituir. É um bando de assaltantes assassinos que, todavia, conseguiu em poucos meses se fazer reconhecer no mundo como Estado Islâmico. Enquanto isso, povos inteiros, como milhões de palestinos, de saarauis, tibetanos, curdos, bascos, catalães, chechenos, irlandeses e outros lutam legitimamente, por muitas décadas, e não conseguem constituir-se em Estados.

Com a queda de Saddam Hussein, a marginalização dos sunitas, somada aos sofrimentos causados pelos bombardeios, à truculência do exército invasor, à forte crise econômica e à generalização da corrupção no novo governo xiita instalado pelos americanos, criou-se um profundo ressentimento que jogou milhares de iraquianos nos braços do radicalismo. Apareceu então um grande número de grupos armados, entre milícias, bandidos e jihadistas iraquianos e estrangeiros associados à Al-Qaeda. Esses grupos foram reforçados por um grande contingente de soldados de Saddam, aqueles todos que perderam emprego e prestígio após a invasão do Iraque pelos americanos em 2003. Os americanos substituíram os sunitas pelos xiitas no poder daquele país, colocaram 
no olho da rua mais de 250 mil militares do regime anterior, os quais se viram sem soldo e sem possibilidade de emprego num contexto de caça aos sunitas e de incriminação dos antigos partidários de Saddam (Caillet, 2015). Tudo isso criou neles um sentimento de frustração e de ódio terrível para com os xiitas, os invasores americanos e os ocidentais em geral. Não se sabe quantos deles, mas muitos partiram com suas armas e sua experiência militar e se juntaram ao movimento jihadista.

Em janeiro de 2006, o maior grupo de combatentes de Al-Qaeda no Iraque, Jaysh Ahl al-Sunnah, liderou um processo de unificação de grande parte das inúmeras facções jihadistas, assim como de muitos chefes tribais, criando o Conselho Consultivo dos Mujahidins do Iraque. No mesmo ano, o Conselho se transformou em Estado Islâmico do Iraque e, a partir do final de 2011, com a saída dos americanos, intensificou seus ataques contra o governo e conseguiu controlar parte do noroeste do país e, em seguida, uma grande extensão dos territórios fronteiriços com a Síria. 0 conflito sírio, desencadeado no mesmo ano pelo Exército Sírio Livre contra o regime de Bachar El Assad, estendeu a influência do EI a este país, onde se associou a outros grupos jihadistas locais, como AlQaeda da Síria (Ajnad Al Sham ou Al Nosra da Síria), o Jeich Al Nasr, Ajnad al Kaukaz, a Legião do Levante, a Katibat al Tawhid Wa Al Jihad (Afrique Inside, 2015).

Com o Daesh, os extremistas islâmicas inovaram ao reivindicar base territorial para a constituição de uma verdadeira entidade estatal, com seus aparatos jurídicos e políticos. Passaram a se interessar pela administração das áreas ocupadas, cuidando em garantir a estabilidade necessária para a gestão de seus negócios locais, contrariamente aos militantes de Al-Qaeda que preferem perpetuar a desestabilização nas áreas em que atuam. Al-Qaeda permaneceu uma organização quase virtual, um imenso holding que terceiriza suas atividades em diversos países. Seus grupos podem agir sem necessariamente ter contato orgânico com o centro. O Daesh, em oposição, pretende dispor de um Estado: controlar um território, emitir moeda, cobrar imposto, ..., restabelecer o Califado de todos os muçulmanos.

A maior parte dos quadros militantes do Daesh se insere ideologicamente numa lógica salafista ainda mais radical, que é chamada neotakfirista ${ }^{9}$. Seus adeptos são particularmente xenófobos e violentamente sectários, considerando todos que não entram em sua seita apóstatas que merecem morrer. São demagogos e sabem usar a mídia para atrair jovens e transformá-los em terroristas. Além de muitos grupos autônomos de jihadistas árabes, diversos movimentos extremistas pelo mundo muçulmano afora se aliaram ao Daesh, a exemplo do Movimento Islâmico de Uzbequistão, da Jammat-ulAhrar no Paquistão ou, ainda, o Boko Haram, na Nigéria (Hashimi, 2016). Todos juraram fidelidade ao Daesh e as cidades que eles conquistam para ampliar o autoproclamado

${ }^{9}$ O Takfirismo foi inventado no Egito, em 1971, por Mustafa Chukri, um dissidente da Irmandade Muçulmana. 0 termo Takfiri significa excomungado em árabe. 


\section{ensaio}

Califado são importantes fontes de renda e de recrutas, além de serem campos de aplicação de suas doutrinas teológico-fascistas. Servem-lhes também como poderosas vitrines para exibir ao mundo o seu poderio de destruição, assim como bases para difundir suas ondas propagandísticas.

Depois dos atentados terroristas do 13 de novembro de 2015 na França, cientistas políticos franceses lançaram um debate polêmico em torno da relação entre a "islamização" e a "radicalização". De um lado, estão os que defendem que os massacres de massa perpetuados naquele momento fossem antes a expressão de uma revolta geracional do que uma questão de religião. Por outro lado, há quem defende o argumento contrário, sugerindo partir do Islã e da hegemonia do discurso salafista para entender as novas facetas do terrorismo.

Enquanto a primeira tese, apoiada nos estudos de Olivier Roy, coloca o motivo religioso em segundo plano, a segunda, desenvolvida originalmente por Gilles Kepel, aponta o fato religioso como o centro da interrogação jihadista (Daumas, 2016). São duas interpretações que se afrontam, sendo que uma, construtivista, enfatiza a ideia de indivíduos ou grupos sociais que seriam animados por interesses profanos e universais e que teriam tendência a utilizar uma cobertura identitária religiosa via "islamização do radicalismo" (Roy, 2015). A outra interpretação, de tendência culturalista, valoriza as mutações históricas do extremismo islâmico que se desenvolveram sobre as ruínas do nacionalismo árabe esquerdista e laico, retomando as teses de Gilles Kepel (Kepel, 1993).

Para além das diferenças, as duas abordagens padecem de um viés. Ambas retratam a violência dos extremistas salafistas, seus modos de expressão e suas hostilidades, sem levar em consideração suas profundas raízes históricas e suas motivações políticas incessantemente renovadas. Não dão a devida importância às questões geopolíticas, à herança colonial e às consequências em termos de racismo e discriminação (Burgat, 2016). Todavia, não se pode entender plenamente o terrorismo islâmico na sua nova roupagem salafista sem inseri-lo nas configurações e reconfigurações das relações de poder entre os dois grandes ramos do Islã, xiitas e sunitas; sem colocá-lo no contexto geopolítico do Oriente Médio e de suas relações com as potências mundiais.

Todos os grupos salafistas beneficiaram das generosidades das monarquias árabes do Golfo, encabeçadas pela Arábia Saudita. No Oriente Médio, os reis xarifados não gostaram da tomada do poder pelos xiitas no Iraque e o surgimento de organizações jihadistas sunitas era para eles um grande meio de frear a formação de um forte eixo xiita que inclui o Iraque, a Síria, Irã e Líbano. Os sheiks do Golfo tentam criar um contraposto eixo sunita através da Arábia, Jordânia e Turquia. No resto dos países árabes, também, a promoção de grupos salafistas locais serve aos Ibn Saud de instrumento para minar qualquer possibilidade de democratização, utilizando-se de uma lógica antiocidental e 


\section{ensaio}

antimodernista, como nos casos do Egito, Argélia, Líbia e Tunísia, pois para eles, assim como para o Daesh, a modernidade é uma abominação.

Na questão econômica, os conflitos têm como pano de fundo o petróleo e o gás. 0 Irã projeta utilizar a Síria como saída privilegiada para o mediterrâneo. Isso reestruturaria totalmente o mercado dessas commodities em detrimento da Arábia Saudita que domina o petróleo, assim como do Qatar, que domina o gás no Oriente Médio. 0 projeto iraniano é um dos motivos que levou esses dois países a participarem ativamente na desestabilização do regime de Bachar El Assad (Mabon, 2016).

A irmandade muçulmana e os países árabes do Golfo financiaram grupos terroristas d'Al-Qaeda e outros grupos salafistas para instalar na Síria, até então regime laico, um Estado nos cânones do fundamentalismo corânico. A identificação dos circuitos de financiamento é muito complexa, mas sabe-se que muito dinheiro sai dos cofres dos dignitários do Golfo para chegar aos jihadistas. Os endinheirados príncipes árabes, cuja riqueza privada se confunde com o erário, saiam de seus países e viajam para o exterior onde se divertem fazendo tudo que é pecado e proibido em seus países. Hipocritamente, para se redimir, compram indulgências transferindo fundos a ONGs e fundações ligadas a organizações terroristas em geral (Monnier, 2016).

Todavia, a partir dos meados de 2013 os sauditas e os cataris começaram a temer que os grupos radicais que ajudaram a formar podem se voltar contra eles. Provocaram então o fim da aliança entre Daesh e Al-Qaeda ${ }^{10}$ e levaram Al Nosra, que é o maior grupo jihadista armado de Al-Qaeda, a entrar em guerra sangrenta contra o ex-aliado (Zelin, 2014). Não sendo mais financiado pelas monarquias do Golfo, o Daesh passou a condenar e a ameaçar a família dos Ibn Saud.

Porém, o reino saudita não perde interesse em perpetuar os conflitos na Síria e no Iraque; não deseja o fim de grupos jihadistas que têm como objetivo instaurar sociedades semelhantes à sua, que decapitam e crucificam os opositores, perseguem os xiitas, enclausuram e apedrejam as mulheres, cortam a mão aos ladrões, interditam os cultos que não sejam seus, execram a democracia, etc. Por isso, os sauditas continuaram a apoiar o Daesh, fornecendo-lhe armas e comprando, no mercado paralelo, o petróleo que ele extrai dos territórios ocupados, com a forte cumplicidade da Turquia (Lombardi, 2015).

Outros países também jogaram a carta dos grupos jihadistas para defender interesses na Síria e no Oriente Médio em geral, acabando por criar o Frankenstein Daesh. Os americanos, ingleses e franceses forneceram armas, incluindo mísseis, para impedir o avanço das tropas de Bachar contra Al-Qaeda e Daesh. As potências ocidentais tomaram partido pela Arábia Saudita e o Qatar, que são grandes parceiros econômicos e militares

\footnotetext{
${ }^{10}$ A rivalidade levou os dois grupos a passar informações à aviação russa sobre as posições das forças rivais.
} 


\section{ensaio}

frente aos quais a Síria pesa muito pouco. Alegaram sustentar a liberdade da Síria através do apoio declarado ao Exército Sírio Livre contra o ditador Bachar, mas nos campos reais de batalha o Exército Sírio Livre acabou sendo diminuído e, de certa forma, confundido com os extremistas islâmicos. Os grupos moderados, laicos e democráticos foram marginalizados e, logo, muitos deles passaram a depender do apoio das organizações radicais. Isso permitiu ao regime sírio de Bachar emplacar na opinião pública o amálgama entre opositores democráticos e terroristas salafistas sanguinários, reduzindo o conflito a uma escolha binária entre Assad e Daesh. Contribuiu a este triunfo de Assad o apoio indiscriminado dos países ocidentais, tanto aos rebeldes ditos livres, quanto aos terroristas de Al-Qaeda e de Daesh.

Atualmente (final de 2016), os ataques da Rússia e da coalizão ocidental provocam perdas territoriais ao Daesh, mas também causam a morte de civis e a destruição de cidades, gerando maior ressentimento das populações locais e alimentando a ideia de que são sempre os sunitas que são castigados pelos bombardeios. Os salafistas enfatizam os sofrimentos de seus irmãos causados pela "agressão" dos infiéis, os cruzados. Filmam a destruição diária de hospitais, escolas, infraestruturas e residências e, todas as horas, lançam na mídia dezenas de vídeos que mostram o massacre de civis pelas incursões externas e ressaltam a humilhação dos padecentes sunitas. Nessa perspectiva, as campanhas ocidentais e da Rússia na Síria apresentam estímulos à adesão de muitos jovens ao radicalismo.

Quando perde o controle de territórios, o Daesh perde também bases para sua propaganda e se lança à procura de outros terrenos para difundir a sua lógica insana de quanto mais sangue for derramado maior será o seu prestígio. Suas derrotas na Síria e no Iraque o levam a atacar na África e no Ocidente, incluindo a Turquia. Busca espalhar o terror pelo mundo através de atentados suicidas, como já vem fazendo particularmente na Síria, no Iraque e na Líbia. Para isso, ele tem muitos candidatos a "homem-bomba", uma longa lista de espera de pessoas prestes para a "operação mártir", todo um contingente formado por jovens oriundos de diversas segmentos sociais e de diversos países: gente do Golfo que vem de famílias ricas, norte-africanos deserdados, outros descendentes de imigrantes muçulmanos que vivem em guetos nos subúrbios da Europa, etc. Há um nome específico criado por Daesh, que é Inrimassi, para designar esses fanáticos que se aproximam das multidões e acionam seus cintos explosivos.

Os inrimassi são voluntários que escolhem essa modalidade de combate assim que chegam aos campos de treinamento. Recebem uma formação militar e teológica específica, enquadramento psicológico rigoroso e doutrinamento mais profundo, isto é, uma verdadeira lavagem cerebral. São muito bem tratados e apreciados pelos quadros do Daesh, que os deixam sentirem-se devedores para com a organização e alimentam neles a culpa de não fazer o suficiente. Fazem-nos pensar que seus atos suicidas lhes garantem a 


\section{ensaio}

posteridade no paraíso muçulmano, embora o suicídio fosse pecado capital no Islã. Mas, para eles o jihadista suicida se auto-sacrifica para uma causa justa e, assim, "se divorcia do mundo terrestre para casar-se com o mundo celeste". Neste, os "mártires" alcançariam o gozo absoluto, o êxtase, o Santo Graal (Mit Post, 2016).

O Daesh conta também com pessoas independentes que passam à ação criminal por iniciativa própria, como os chamados "lobos solitários", movidos, em alguns casos, por fanatismo religioso ou por distúrbios psiquiátricos e, em outros casos, por razões autenticamente políticas, por decepções pessoais traumáticas, por vícios patológicos ou por outra causa de interesses mafiosos que fazem do terrorismo um negócio lucrativo. Todos se dispõem a morrer ou mandar morrer para matar indiscriminadamente homens e mulheres inocentes com os quais não têm nenhuma relação pessoal.

A comunicação é uma de suas principais armas que lhes permite atrair milhares de militantes, vendendo-lhes teorias de conspiração em que alegam que todos os poderes e instituições no mundo são manipulados por forças satânicas que operariam contra a justiça em geral e que precisa combater. Colocam-se como vítimas e propagam a ideia de que, com a fé e a coragem, poderiam conquistar o planeta inteiro e reestabelecer a justiça. Possuem um tentacular e moderno aparato de propaganda em muitas línguas: revistas, canais de televisão, videogames, canais em redes sociais, etc. (Heritage Foundation, 2015).

Na sua propaganda, vale tudo: denunciar os governos, a humiliação, o Ocidente, o imperialismo, a laicidade, a liberdade da mulher, a heresia, particularmente ${ }^{11}$. Enquanto denunciam, os terroristas exaltam o heroismo, o orgulho, a rebelião, o martírio, a aventura, o enriquicemento, a força, a violência; tudo que possa excitar um jovem revoltado e desnorteado. Grupos de jovens vulneráveis (psicologica ou economicamente) buscam as vezes sites sensuais e se deparam com a propaganda dos fanáticos. São inúmeros os foruns jihadistas de discussão, que servem para recrutar pessoas, reunir fundos e garantir a propaganda. Até a década de 2000, eram hospedados gratuitamente pelas firmas de serviço Internet sediadas em todos os cantos do planeta. A partir de 2010, com o facebook, que é menos controlável e que permite anonimato, a audiência dos grupos jihadistas tomou maior dimensão (Guibert, 2015). Seus foruns são verdadeiras escolas de terrorismo: fornecem manuais de guerra, receitas de bombas, formas de criptagem das comunicaçoes, vídeos de motivação, periódicos de informação. Incitam os atentados e estimulam aqueles lobos solitários descolados no Ocidente a passar à ação.

\footnotetext{
${ }^{11}$ Denunciar o imperialismo é uma hipocrisia, pois há convergência clara de interesses entre o jihad salafista e o imperialismo. Ambos buscam redesenhar o mundo segundo uma lógica que se opõe à lógica das nações, porque as nações sempre resistem às pretensões hegemonistas.
} 
Com sua máquina de propaganda, os quadros do Daesh atraem suas recrutas, principalmente jovens. São bons oradores, prometam ação, dinheiro e divertimento na terra e o Éden, no céu. 0 sucesso propagandista do Daesh pode se medir pelo grande número de grupos terroristas que surgiram em muitos países, disputando o lugar de representante do autoproclamado Califado em seus respectivos feudos.

Qualquer crime ou assassinato que ocorre no mundo e que pode ter alguma marca da comunidade muçulmana se vê logo reivindicado e apropriado pelo Daesh. Isso faz parte da sua estratégia propagandista que busca exibir poder de destruição e projetar uma imagem de herói justiceiro. Nesse sentido, a mídia mundial contribui para validar a perigosa tendência de imputar todos os crimes em massa à arregimentação da organização terrorista. A imprensa internacional participa, direta ou indiretamente, na construção de uma imagem que estrelatiza os terroristas, estimulando a atração pelo jihadismo radical de jovens vulneráveis que buscam dar um sentido ao seu mundo desprovido de conforto, espiritualidade, pertencimento e afeto.

A mídia internacional comete o erro de dar unidade e consistência a miríades de ações mais ou menos inspiradas do terrorismo jihadista. Confundem-se todas as matanças cometidas, que seja por grupos organizados ou por indivíduos solitários, pessoas alinhadas com os princípios teológicos do salafismo ou que vivem totalmente em desacordo com o que ele prega, podendo ser considerados infiéis na perspectiva fundamentalista e, portanto, condenáveis. Aproveitar essa publicidade mundial faz a força do Daesh. Porém, ao reivindicar atos de pessoas pouco ortodoxas e cujo modo de vida contraria os princípios do fundamentalismo corânico, corre o risco de agir em contradição com seus valores, de revelar assim seu oportunismo e provocar desconfiança entre seus seguidores. Como, por exemplo, as facções radicais podem reivindicar a paternidade de um ato terrorista realizado por algum alcoólatra ou drogado numa cidade europeia, quando o consumo de álcool e de drogas é punido por morte nos territórios onde legislam? Como poderiam, um outro exemplo, se vangloriar de um homossexual europeu que comete assassinato e transformá-lo em soldado de Alá, quando em seus feudos enterram vivos qualquer um que não seja estritamente heterossexual? Com suas contradições, todas as ideologias terminam por se descreditar.

Desmascarar o radicalismo dos islamistas é mostrar suas contradições, assim como revelar como seus protagonistas são teofascistas, monstros criados por uma humanidade doente, a mesma que está a promover, pelo mundo inteiro, diversos movimentos fundamentalistas, conservadores, reacionários, populistas e racistas. No contexto de crise geral da sociedade, crise dos símbolos, da economia e da espiritualidade, tudo que pode reunir os homens (a religião, a cultura, a política, a arte, a amizade) está sendo ameaçado. Nessa obscuridade, surge uma profunda ansiedade, o temor do caos, do aniquilamento 
recíproco, do incêndio universal. As paixões que nascem do medo e do ódio podem levar a qualquer ordem autoritária e totalitária, como ocorreu no final do século XIX ou no período entre as duas guerras mundiais. Interromper esse processo passa necessariamente pela colocação do humano no centro dos interesses de forma concreta e particular, diferente do modo universalista, homogeneista e massificador, que tem sido tradição em nossa civilização agonizante.

\section{A alteridade como antídoto do fanatismo.}

Na relação alteritária, o homem valoriza os outros diferentes, vê-se com eles como elemento interdependente e complementar. Nessa relação interpessoal, “... as experiências particulares são preservadas e consideradas, sem que haja a preocupação com a sobreposição, assimilação ou destruição..." (Significados, 2016:1). A consideração e o apreço das diferenças apazíguam o espírito agressor e abrem nele as portas da cooperação na paz. Sabe-se que quando manifestamos inimizade e soberba ao outro, a menor observação que formulamos a seu respeito, mesmo que seja justificada, será interpretada como afronta, como injúria passível de gerar reações agressivas. Mas, quando, ao contrário, lhe testemunhamos sincera simpatia e franca consideração, valorizamos a sua cultura, respeitamos suas crenças e suas origens étnicas e sociais, aí, sim, podemos alertá-lo sobre o que achamos nele de incorreto e criticável, sem correr o risco de causar ofensa e gerar animosidade (Maalouf, 1998).

O muçulmano se vê incriminado a cada vez que ocorre um crime cometido por fanáticos islâmicos, absurdamente em nome de Alá. Toda vez, aumenta o ódio que se tem dos muçulmanos no mundo em geral, culpando a religião de Maomé pela intolerância e a brutalidade, atributos que lhe seriam inerentes. Cresce a ideia de que o Islã seja incompatível com a modernidade, a liberdade e a democracia; contrário aos direitos do homem. Estende-se o amálgama entre Islã e fundamentalismo, escondendo o racismo vis a vis dos povos de crença islâmica. Condenado assim, à revelia nessa visão implacável, o muçulmano se sente injustiçado e humilhado; vê-se recriminado, sua religião satanizada na base da crendice, da hostilidade e do desprezo e se contrai.

Comparando com o cristianismo, não se pode dizer que historicamente essa doutrina fosse tolerante e respeitadora das liberdades, diante de todos os crimes cometidos no passado em nome da igreja e que foram abonados pela imensa maioria dos cristãos. Isso não significa que a religião de Jesus seja, na sua essência, violenta, despótica ou racista, pois está hoje em harmonia com os direitos humanos e com a democracia; admite coisas que rejeitava veementemente, como o uso de contraceptivos e o casamento homossexual, por exemplo. A democracia moderna é obra do Ocidente onde a religião é fundamentalmente cristã, mas se a igreja acompanhou (não sem reticências) os últimos 


\section{ensaio}

movimentos libertadores do homem, ela não os criou, nem os estimulou. De qualquer modo, como mostra bem a história do século passado, nenhuma doutrina por si é libertadora; todas podem derrapar, ser pervertidas e transformadas em tiranias; nenhuma detém o monopólio do fanatismo, do mesmo modo que ninguém se apropria de todo o humanismo (Maalouf, 1998).

Embora a doutrina islâmica não seja um paraíso da tolerância, a história destaca o fenômeno que representou a mensagem maometana e revela que os muçulmanos, quando eram fortes conquistadores, conviviam pacificamente com outras culturas nas terras que controlavam; não se incomodavam com a presença de cultos e costumes alheios. No final do século XIX, para se referir à história mais recente, Istambul, capital da maior potência muçulmana de todos os tempos, contava na sua população uma maioria não muçulmana que vivia em paz, formada por gregos, armênios e judeus, enquanto que no mundo cristão as minorias religiosas, como as judias, cátaras, huguenotes e outras consideradas infiéis, heréticas ou cismáticas, ainda eram perseguidas (Martina, 1996).

Mas, para que serve a tolerância do passado se hoje tudo que vem do mundo muçulmano são notícias de apedrejamento de mulheres, degolamento de jornalistas, sequestro de meninas e turistas, ação camicase, uso de armas químicas e outras loucuras apavorantes? Diante disso, fica evidente que aqueles princípios primários de tolerância, que se encontravam na época da ascensão muçulmana, em vez de serem adaptados, renovados e ampliados, foram rudemente escasseados. Isso contradiz o mandamento do Ijtihad, que prega pelo empenho do muçulmano na aparagem e no desbaste do caráter, na compaixão e na elevação da alma. Portanto, a direção que os radicais muçulmanos desejam imprimir ao processo histórico da civilização islâmica é anti-islâmico. Parece ser também inversa daquela que se observou no percurso cristão.

De fato, a igreja que era durante centenas de anos bastante intolerante e totalitária, se abriu e aderiu, progressivamente, aos preceitos da modernidade. Enquanto isso, os islamistas fundamentalistas do momento, caminham pelo rumo regressivo, sonhando com um imaginário direito islâmico intertemporal, puro e original que não admite adaptações, nem diversidades no culto e nas interpretações da Mensagem de Maomé. Tal perspectiva coloca o mundo muçulmano, a princípio aberto e transigente -até porque a sua base material era o comércio-, no caminho da exclusão, do absolutismo e da segregação. A intolerância se generaliza e se exerce tanto em relação aos não muçulmanos, quanto vis a vis dos correligionários, quando estes não são da mesma confissão ou quando divergem na realização de determinados ritos e na interpretação das sagradas escrituras.

Os enfrentamentos violentos entre os próprios muçulmanos de diferentes ramos ou de diversas etnias e idiomas estão sendo constantes e crescentes. Sabe-se que as extremas consequências da intolerância nas populações muçulmanas são incomparáveis, 


\section{ensaio}

em termos de perdas humanas, exílio e sofrimento, aquelas, também condenáveis, que se devem aos atentados contra não-muçulmanos. Sabe-se, também, que os atos de matar são organizados por líderes fanáticos, milicianos, paramilitares e bandidos, que das leis do Islã só conhecem, em fragmentos descontextualizados, aquelas que possam ser interpretadas de forma a legitimar suas atrocidades. Esses fatos são um sinal de que o problema de fundo não é essencialmente religioso, mas está num certo mal-estar generalizado do mundo muçulmano. Não se trata, digamos, de isentar a doutrina islâmica das crueldades dos fanáticos, mas de alertar contra as falsas interpretações que imputam à religião todos os males da violência, reproduzindo velhos prejulgamentos de suposta natureza agressiva imutável do Islã. Vale aqui observar que da mesma forma que não se pode dissociar uma crença do destino de seus adeptos, não se pode exagerar a influência da religião ou de qualquer outra ideologia sobre os povos. Neste sentido, a título de comparação, se é legítimo interrogar-se sobre o que o comunismo fez da Rússia, é igualmente legítimo perguntar-se sobre o que os russos fizeram do comunismo (Maalouf, 1998).

Os radicais muçulmanos não hostilizam os ocidentais por motivos religiosos, mas porque se sentem dominados, menosprezados, explorados pelo Ocidente hegemônico e vêm seus parâmetros civilizacionais ameaçados de extinção. Sentem-se negados e oprimidos pelos outros diferentes e reagem com o mesmo comportamento sectário e repressivo, rejeitando toda manifestação de alteridade. Os mais frustrados e virulentos defendem a supressão de todas as marcas da cultura ocidental em suas culturas, mesmo que seja através do derramamento do sangue. Focalizar a responsabilidade por tal drama no Islã, ignorando a realidade histórica dos povos, marcada pela humilhação e subjugação, torna o fenômeno ininteligível. Aliás, a cólera contra a cultura ocidental capitalista não se restringe ao mundo muçulmano. A propósito, vale lembrar como a revolução cultural na China, que não teve nenhum marco religioso, pretendia acabar com todos os traços da cultura capitalista ocidental.

É curioso ver o fundamentalista recorrer ao discurso terceiro-mundista dos anos de mil novecentos e sessenta, para "justificar" suas ações assassinas contra não-muçulmanos, contra os "infiéis". Denunciar o imperialismo oferece, de fato, uma legitimação externa mais sólida e de maior alcance do que aquela que a teologia da Sharia pode apresentar. Esta, por sua vez, fica reservada aos correligionários como motivação em suas vertentes interpretativas do ódio e das agressões mortíferas internas ao mundo muçulmano. Em ambos os casos, contudo, a violência somente se desenvolve quando encontra campos sociais e psicológicos favoráveis, grupos que a aclamam. Ela vinga quando consegue mobilizar indivíduos que já não têm mais nada a perder, que se sentem excluídos, frustrados e prostrados. Situações estas que pode levar qualquer um a detestar sua vida e, no extremo, a decidir sacrificá-la por alguma causa. Em ambos os casos, também, a ação militante dos que se dizem soldados de Alá, apresentada por eles como 
corajosa e desinteressada, encobre sempre a busca de uma compensação a problemas de ordem privada e psicológica, como em todas as formas de violência humana, coletivas ou individuais. Antes de se tornar homem-bomba, o terrorista deixa de se considerar pessoa deste mundo, renega o amanhã que ele não deseja viver, porque se anuncia semelhante ao hoje. Aguarda então pelo momento de realizar a sua última ação lendária, quando se explode como fogo de artifício no meio de uma feira ou se arremessa contra o tanque do inimigo (Izerrougene, 1998).

O terrorismo islâmico não é puro reflexo fatal de uma suposta história muçulmana violenta. É grande erro insistir em limitá-lo a uma estratégia fria e assassina de agentes maléficos, ignorando as tensões e distorções contemporâneas, produtos da colonização e das ditaduras nacionais, que obstruíram toda possibilidade de modernização social. Tanto num caso como no outro, os dominadores fizeram tábua rasa de muitos séculos de história, de evidências geográficas, de fundamentos da diversidade cultural e linguística e de realidades étnicas. Quando a oposição só pode evoluir entre dois extremos, submeter-se à hegemonia ou renunciar a direitos fundamentais, a violência se torna inevitável. A angústia que resultou da impossibilidade de todas aquelas comunidades de se situarem na cultura oficial e de se definirem enquanto identidade independente e autêntica impediu qualquer função integradora. Só lhes restou lutar para manter a sua singularidade e preservar a sua própria cultura da monopolização da ação e da fala pelos colonizadores europeus, primeiro, e, em seguida, pelos regimes autoritários nacionalistas que precipitaram seus respectivos países em guerras civis, numa grande parte do mundo muçulmano. As ditaduras, que se pretendiam laicas e republicanas, se revelaram, no final, verdadeiras incubadoras do fanatismo religioso. A República sem democracia foi um contrassenso desastroso.

A partir dos anos de mil novecentos e oitenta, após poucas décadas de independência, as contradições socioeconômicas, exacerbadas pela falência administrativa, pelo clientelismo, pela corrupção e asfixia das liberdades, aceleraram a erosão da legitimidade histórica do poder. Na ausência de canais democráticos de expressão, a oposição tomou forma de um motim popular que sacudiu os países árabes em geral. A reação dos donos do poder, isolados da sociedade, era a de designar os fundamentalistas como interlocutores, cedendo-lhes espaço crescente para a introdução da Sharia na legislação e no direito (Marty 1984). Na lógica da competição política, o fundamentalismo foi explorado para combater todas as forças de progresso. Os islamistas, francamente apoiados na época pelo Ocidente, souberam explorar a crise e utilizar a religião como verdadeiro instrumento de mobilização e contestação. Em vez da emergência de forças democráticas e laicas, como se esperava, foi uma irresistível ascensão islamita radical que se mostrou.

Os fundamentalistas, que até então eram vistos como inimigos da nação árabe, a soldo do imperialismo, começaram a adquirir legitimidade e importância na população e 
passaram a canalizar o descontentamento contido para pregar um passeismo impetuoso e responder a um Estado que era a emanação da violência. Declararam guerra aos governos que, por sua vez, montaram juntas militares para reprimir impiedosamente qualquer oposição. A violência explodiu e degenerou em guerras civis nos quatro cantos do mundo muçulmano. Ainda, espalhou-se mais rápida e intensamente no tecido social após as últimas incursões militares ocidentais, estimulando o aliciamento de mais adeptos e mais apoiadores.

Utilizando-se de uma força bélica desmedida, do bombardeio das populações, da destruição do patrimônio e da prática da tortura e das execuções, a invasão estrangeira não podia iludir ninguém com sua pressuposta promoção da democracia nesse mundo tido como pré-histórico. Pelo contrário, veio se somar a um vasto leque de injustiças e agressões históricas, assim como aos crimes correntes cometidos por Israel contra os palestinos, com o aval e o apoio das potências ocidentais, acentuando o sentimento de humilhação nos agredidos e evidenciando o seu caráter imperialista.

Para a maioria dos muçulmanos no mundo, está claro que os ocidentais em geral não querem que os não-ocidentais lhes pareçam no seu desenvolvimento material e intelectual, mas tão somente que lhes obedeçam. E não faltam motivos, tanto remotos quanto atuais, para tal sentença. Um deles, mais frequentemente citado pelos intelectuais árabes, se refere ao episódio do Egito sob os governos reformadores de Mehmet Ali (ou Muhamed Ali) e seus seguidores, os quais entenderam, a partir dos meados do século XIX, que para alcançar o Ocidente no seu progresso era necessário imitá-lo. Promoveram então uma ocidentalização voluntarista que logo se mostrou capaz de edificar um Estadonação moderno à altura dos Estados europeus. Mas, como incomodavam por seu sucesso as potências europeias que os consideravam ameaça aos seus interesses na região, uma coalizão, liderada pela Inglaterra, bombardeou Alexandria em 1882 e pôs o Egito sob o protetorado britânico (Maalouf, 1998). Quebrou-se o sonho da modernidade alimentado em todo o mundo árabe, uma vez que o Egito ocupava lugar de liderança na região. E, para agravar a situação, os ingleses, aplicando a velha estratégia de dividir para reinar, sustentaram, contra os reformadores insubmissos ao poder colonial, todas as instâncias que recusavam as mudanças de modernidade iniciadas por Mehmet Ali. Estes segmentos, minoritários e conservadores, já contavam com o financiamento da monarquia saudita, interessada em difundir o wahabismo, que é a base doutrinária dos antirreformistas egípcios e que representa a fonte de todos os grupos islâmicos radicais de hoje no mundo.

O grande fato histórico e inédito é que, nos últimos séculos, a civilização ocidental se tornou referência em todos os domínios materiais e intelectuais, tanto que as outras civilizações se viram marginalizadas e reduzidas ao estado de culturas periféricas, ameaçadas de extinção. A ciência do Ocidente se tornou a ciência do mundo, a sua medicina 


\title{
ensaio
}

é a medicina do homem, a sua filosofia é a Filosofia e a sua arte é a Arte, colonizando e uniformizando todos os campos da vida, em todos os continentes. Desde há mais de meio milênio, tudo que influencia duravelmente as ideias dos homens, sua organização política e social, seu entretenimento, sua saúde e seu ambiente, procede do Ocidente. 0 capitalismo, o comunismo, as novas instituições, os padrões de consumo, o fascismo, o nazismo, a psicanálise, a eletricidade, o satélite, o nuclear, o avião, a penicilina, o rádio, a televisão, o automóvel, a informática, os direitos humanos, tudo isso e outras invenções benignas ou malignas foram obras do Ocidente (Maalouf, 1998). Por onde quer que se viva, toda modernização é sinônimo de ocidentalização, quando não é de americanização.

Essa realidade não é sentida da mesma forma por um ocidental e o não ocidental. Fazendo essa comparação, o escritor Maalouf deixa claro que:

\begin{abstract}
... [Os ocidentais] avançam, se adaptam e transformam, sem perder de vista a sua essência cultural e, na sua quase totalidade, quanto mais se modernizam, melhor se sentem em harmonia com suas culturas. Nos demais, o resto do mundo, todos que pertencem a culturas desfeitas, a receptividade à mudança se coloca em termos diferentes. Para um chinês, um africano, indiano, turco, indonésio, ameríndio, e também para o persa ou o árabe, a modernização sempre implicou certo abandono de uma parte de si. Pode-se imaginar o grau de desolação e desorientação de muitos povos não ocidentais, para os quais, há muitas gerações, cada passo na sua história é acompanhado de um sentimento de autonegação [...] Tiveram que reconhecer que seus modos de produzir e consumir eram obsoletos, que sua medicina tradicional era supersticiosa, que seus utensílios, armas e ferramentas eram arcaicos, que seus sábios não contam mais para nada. Assistem à infamação de suas religiões e à morte de seus idiomas, enquanto se vêm obrigados a falar inglês se não desejam continuar à margem da história. [...] Quando falam com o ocidental, sempre na língua deste é que o fazem, quase nunca na sua própria língua. É sintomático ver que em todos os países da África, Ásia e Oriente Médio, encontram-se milhões de pessoas capazes de falar inglês, espanhol ou francês, ao passo que são raríssimas as pessoas francesas, inglesas ou espanholas que julgam atraente aprender o turco ou o árabe. (Maalouf, 1998:84/85. Trad. Livre).
\end{abstract}

Mesmo que suscite entusiasmo e acomodação, a modernização nunca é aproximada sem o sentimento de renegação, sem a apreensão dos perigos da assimilação, sem uma depressão identitária. Quando a modernidade carrega a marca da dominação e da discriminação, fica mais fácil induzir certas pessoas a levantar a bandeira do arcaísmo para afirmar suas diferenças. Na Rússia, por exemplo, teve que esperar a revolução bolchevique para que os russos adotassem o calendáriogregoriano, porque até então tinha-se o sentimento de que desistir do calendário juliano significava admitir a supremacia do Catolicismo sobre a Ortodoxia. Era apenas um símbolo, podia-se objetar, mas tudo na história se manifesta através de símbolos: a glória, a derrota, a prosperidade, a miséria e, sobretudo, a identidade. Para que uma mudança seja aceita, não basta estar em conformidade com o seu tempo, mas é também necessário que não se choque com os símbolos dos povos e que nunca dê ao sujeito a impressão de capitulação e de negação de si. 
A globalização é capitalista e é antes de tudo cultural hegemonista, rimando com imperialismo. Por isso, há comunidades, não somente no mundo muçulmano, mas em todo o planeta, até mesmo nos países modernos e desenvolvidos, que duvidam e se perguntam sobre o lugar de suas culturas e especificidades no cenário atual de uniformização acelerada. 0 que será de suas tradições, línguas, prestígios, artes, música, culinária e de outros saberes ancestrais, de outras singularidades? Essa angústia pode levar os mais desapontados e frustrados, aqueles que se sentem viver num mundo que não lhes pertence e onde as regras são ditadas de fora, que se acham num mundo alheio, órfãos e intrusos, à impressão de que perderam tudo, prontos a desejar o apocalipse.

Depois da queda do muro de Berlim, o capitalismo triunfou, certo, mas apesar de estender sua influência sobre o conjunto dos continentes, configura um modelo em crise, incapaz de resolver os problemas de pobreza e de desigualdade em seus próprios territórios de origem; incapaz de preservar o meio ambiente, estancar o racismo, a delinquência, o desemprego, a indigência, a corrupção, o uso das drogas e outros males. Nisso, aliás, se encontra um dos maiores paradoxos da história, em que o modelo mais atraente de sociedade, o que venceu os demais, se debate com a falta de perspectivas e duvida de si. Nessas circunstâncias de horizontes fechados no capitalismo globalizado, após a desilusão geral em relação ao comunismo derrotado e ao nacionalismo confiscado, um jovem árabe, africano ou persa, que sonhasse em mudar a ordem estabelecida e se revoltar contra o autoritarismo, o arbitrário e a miséria, não encontrará respaldo civil nenhum para suas aspirações. Outrora, podia integrar uma organização socialista na qual encontraria sensibilidade aos seus problemas pessoais e sentido à sua vida coletiva, ou inserir-se num partido nacionalista que teria acomodado suas necessidades de identidade e de progresso. 0 jovem que busca hoje o seu lugar num mundo movediço, egoísta e individualista, pode ser facilmente tentado a atender suas necessidades de identidade, de inserção social, de ação, de espiritualidade e de compreensão de uma realidade por demais complexa, através do recurso à religião e a valores e símbolos antigos. Tornar-seia, assim, recruta potencial de movimentos fundamentalistas e extremistas, tal como o radicalismo islâmico que, oportunamente, prega o passeismo, exalta o heroísmo, cultiva o martírio, profetiza a vitória e promete o paraíso.

Como ocorre que uma afirmação altiva de pertencimento religioso, que parecia, há poucas décadas, indecorosa, apareça agora natural e legítima, não somente no mundo muçulmano, mas em tantos países do planeta? Que motivo leva homens e mulheres de todas as origens, no mundo inteiro, a redescobrir hoje seu parentesco religioso e asseverálo de diferentes formas, enquanto que no passado recente esses mesmos homens e mulheres priorizavam os aspectos sociais e políticos de afirmação? 0 que faz, por exemplo, um operário judeu na França, que sempre colocou seu pertencimento ao proletariado internacionalista como elemento preeminente da sua identidade, passar um dia a usar 
uma quipá e se perceber como judeu antes de qualquer outra identificação? Por que um egípcio que sempre se dizia pan-arábico até a década de 1980, agora cria barba, se enfia na mesquita e tenta reproduzir o modo de vida dos primeiros companheiros de Maomé? Como um executivo desenvolvimentista brasileiro se aposenta e se torna pastor evangélico? $\mathrm{O}$ que leva uma militante feminista norte-americana a se tornar beata dona de casa? A resposta é complexa e nenhum motivo isolado pode formar uma explicação satisfatória, mas é incontestável que o desmoronamento do mundo comunista e a globalização feita na base de um capitalismo cambaleante cumprem um papel significativo nessa evolução.

De um lado, durante mais de um século, o marxismo prometia estabelecer no conjunto do planeta uma sociedade nova da qual todos seriam iguais e a religião banida. 0 fracasso desse projeto, tanto nos domínios econômicos e políticos, quanto nos âmbitos morais e intelectuais, teve como consequência a reabilitação das crenças que se pretendia sepultar. Refúgio espiritual e identitário, a religião passou a ser, de Johanesburgo a Cabul, uma bandeira evidente para muitos. Do outro lado, a globalização acelerada provoca uma necessidade maior de afirmação identitária e gera, em razão da angústia existencial que acompanha a pressão das bruscas transformações materiais e tecnológicas, uma carência em valores espirituais. Ora, nenhum campo de vida, fora a religião, se propõe a dar resposta a essas duas necessidades. No cenário humano de confusão generalizada, o pertencimento religioso aparece como último a poder atender a tantas penúrias, transcendendo todos os pertencimentos tradicionais que se referiam à classe social, à política, à nação e outros motivos que não foram menos violentos.

Nunca antes os homens tiveram tantas coisas em comum: conhecimento, imagens, expressões, símbolos, instrumentos, mas isso não impede que uns ou outros queiram afirmar suas diferenças com maior proeminência. Trata-se de uma relação conflituosa entre a necessidade da singularidade e a exigência do universal. Neste sentido, o retorno aos valores religiosos se apresenta como o meio intermediário de sair da antinomia, uma vez que as comunidades que se formam em torno de motivos religiosos são tribos planetárias. São tribos por conta do seu conteúdo identitário restrito, e são planetárias, porque não têm fronteiras. De fato, a adesão a uma fé ultrapassa todas as raias nacionais, raciais, sociais, e forma em si um particularismo global, isto é, um modo próprio, a mais tangível e mais enraizada maneira de se ver universal. Isso é um fenômeno inédito, que se inscreve no processo de transformações globais contemporâneas, não podendo ser uma volta a alguma situação anterior, mas, sim, um avanço no caminho da verdadeira universalização. Nessa perspectiva, superar o pertencimento a tribos planetárias e suas consequentes separações e discriminações pressupõe, necessariamente, uma concepção mais ampla da identidade e, portanto, maior consciência humanista. Superar o restrito pertencimento a tribos implica no encorajamento de cada um a assumir a sua diversidade, a conceber a sua identidade como sendo a soma de seus diversos parentescos, em vez 
de confundi-la com um só, erguido como supremo e transformado em instrumento de separação e exclusão e até em motivo para guerras.

As sociedades também serão levadas a admitir seus múltiplos pertencimentos que afeiçoaram e continuam a afeiçoar sua identidade; se esforçar para mostrar, através de símbolos explícitos, essa vontade de assumir suas diferenças para que cada um possa se reconhecer nas imagens do país onde vive. Assim, o homem pode se sentir encorajado a se envolver com a diversidade e não permanecer como espectador inquieto e, por vezes, hostil, por não poder se conceber socialmente fora de uma referência cultural específica e exclusivista.

Para ilustrar esse ponto de vista, cabe o exemplo da França, que é um país de crença predominantemente cristã, o que não lhe impede de reconhecer suas outras dimensões religiosas, como a protestante, a judaica, a muçulmana e até mesmo a ateia, tendo cada uma delas papel significativo na vida daquele país. Da mesma forma, no que diz respeito à língua, o francês possui, ele também, uma identidade a múltiplos pertencimentos, sendo essencialmente latino, mas com influências germânicas, célticas, africanas, eslavas, árabes e outras que o enriquecem sem para tanto o desvirtuar. Assim que se percebe em si, em suas origens e sua trajetória, em seus diversos tributos e aportes, diversas contribuições, diversas conjugações e influências, o cidadão francês, como outros cidadãos de outros países, se envolverá numa relação diferente com o outro, uma relação de solidariedade humana, que não será mais de adversidade nem de segregação, mas de alteridade.

O mesmo raciocínio pode ser replicado para a Europa como um todo. Na medida em que constrói a sua unificação, o continente concebe a sua identidade como a soma de todos os seus pertencimentos linguísticos, religiosos, étnicos e outros. 0 projeto de união não se completa se não reivindicar cada elemento da sua história e da cultura de cada um de seus membros, assegurando que todos possam se sentir plenamente europeus sem deixar de viver a especificidade que lhes confere a sua nação ou o seu território de origem. Construir uma nova Europa sugere necessariamente a construção de uma nova identidade para si, para cada um dos países que a compõem e, por extensão, colaborar na elaboração de um novo humanismo. Este novo humanismo se constrói na solidariedade e alteridade, pela ampliação do pertencimento e a valorização dos inúmeros vínculos entre os povos e suas culturas.

Pode-se, por exemplo, alegar que os países árabes e a Europa ocidental têm a mesma ascendência gregosemítica, o que forma por si um forte motivo histórico de aproximação. E quando temos a mesma genética, tendemos a padecer das mesmas doenças e a nos colocar no mesmo caminho da terapia. Nessa perspectiva, cada um pode se sentir no mundo humano entre os seus, onde todos têm mitos, superstições e arquétipos comuns, entoam os mesmos adágios e as mesmas rimas, tecem as mesmas crenças, aspiram aos 
mesmos sonhos. Nessa humanidade, quando remontamos a um número relativamente pequeno de gerações, descobrimos que somos todos primos.

Atualmente, o conhecimento progride rapidamente e a sua propagação se faz com mais velocidade, de tal forma que as diferenças entre as sociedades humanas tendem a diminuir. No entanto, os novos meios de comunicação, embora aproximem os povos, ainda veiculam a ameaça de uniformização e geram a necessidade de afirmar diferenças e particularidades. Mas hão de estimular, no final, a tomada de consciência do destino comum. Com isso, pode-se esperar a emergência de uma nova noção de identidade, que seria concebida como a soma de todos os nossos pertencimentos, dentre os quais o da comunidade humana se tornaria cada vez mais relevante, sem para isso apagar os nossos pertencimentos peculiares. Essa equação somente se resolve quando a globalização se afirmar como processo enriquecedor de mesclagem e de integração de todos, atenuando o seu aspecto uniformizador, empobrecedor e contestável.

Duas frentes pacíficas e complementares de combate se abrem etêm na comunicação o seu campo privilegiado de batalha: de um lado o combate em prol da universalidade dos valores e, do outro lado, o imperativo da luta contra todas as formas de hegemonia (política, econômica, mediática, etc.), contra o unanimismo embrutecedor, contra tudo que inibe a expressão da diversidade cultural, linguística, artística, intelectual. Trata-se de um combate firme, franco, perspicaz, legítimo; sem medo, aberto para o futuro. Um combate humanista que atrairá a simpatia dos humanos que irão imperativamente entender a necessidade de cooperar para atenuar seus problemas comuns de desemprego, de instabilidade política, poluição, saúde pública, seca, envelhecimento, violência urbana, e todos que se colocam em termos globais. 0 êxito dessa cooperação humana passa necessariamente pela alteridade, isto é, a compreensão, valorização e aproveitamento de todas as formas, centrais e periféricas, de estar. Isso pressupõe a desmonopolização do pensar o mundo e do estabelecimento dos valores humanos e implica no fim do excepcionalismo ocidental. Somente assim é que se abre caminho para estender a todo humano um valor intrínseco, restituindo a todos a possibilidade de ser diferente sem para tanto ser desigual.

De fato, pensar nas outras possibilidades de ser significa cessar de ver o mundo como extensão de si, numa visão egocêntrica que busca, na realidade, preservar seus privilégios e estabelecer que o seu modo de ser defina o modo de ser dos outros, abafando toda forma de alteridade. Respeitar o outro na sua diferença não é trazê-lo para o nosso modelo de vida e, por extensão, transformar o planeta num grande empório metropolitano, regido por princípios reducionistas. 0 princípio da democracia é um exemplo que é sempre visto como sinônimo de justiça e liberdade e que tende a ser imposto em sociedade alheias, embora possa estar carregado de tirania, servilidade e discriminação. 
Compreender, respeitar e valorizar outras formas de estar no mundo pode ser de grande utilidade para enfrentar os novos desafios planetários, como o esgotamento da biosfera, as mudanças climáticas, a violência humana, a carência espiritual, o egoísmo predador, etc. As sociedades minoritárias, como as indígenas, podem nos ensinar, através de suas culturas e tradições, a repensar a relação com ou outro e com o mundo exterior, numa forma que não seja excessivamente fundada nos interesses materiais egoístas; que não seja na base de um sistema econômico poluidor. Elas podem nos treinar a viver o presente e reduzir a nossa obsessão pela acumulação, nos aprender a viver com pouco, a ser tecnologicamente polivalentes e flexíveis, em vez de depender de uma estrutura de produção e consumo cada vez mais pesada e mais perversa em termos socais e ambientais. Podem nos ensinar, desde que abandonarmos o nosso complexo de superioridade e estimarmos a colaboração e a solidariedade; desde que voltarmos à natureza como lugar do qual depende toda a autonomia econômica, política e existencial. Nessa cooperação, é evidente que se deve impor a todos os parceiros o respeito dos direitos fundamentais do homem e da mulher. As tradições, nossas ou alheias, só podem ser aprovadas na medida em que reverenciam os direitos fundamentais, pois admitir tradições discriminatórias equivale a desprezar suas vítimas. Em outros termos, a modernidade não deve apagar as particularidades, mas não há especificidades quando se trata de valores fundamentais de vida, justiça, liberdade, participação política, igualdade racial e de gênero, etc. Dentro desses valores, a modernidade é indivisível.

Dequalquer modo, uma vez que se desenvolva a alteridade, relações de reciprocidade e de respeito se estabelecem entre os povos e entre os indivíduos, valores éticos e morais universais emergem necessariamente por trás das diferenças. Nessas relações de reciprocidade e respeito, os contemporâneos podem ser encorajados a assumir seus múltiplos pertencimentos, conciliar suas necessidades de identidade com uma abertura franca e descomplexada para as diferentes culturas e não se sentir mais constrangidos a escolher entre a negação de si e a negação do outro. Para que uma pessoa se sinta à vontade no mundo de hoje e nele se inserir de forma positiva, é necessário que não seja obrigada a abandonar sua identidade. Ninguém deve ser constrangido a se expatriar mentalmente cada vez que toma uma refeição, abre um livro, discute ideias, assiste a um filme, reflete sobre o mundo, etc. Cada um deve poder se apropriar da modernidade, no lugar de ter sempre a impressão de estar a tomá-la de empréstimo.

Hoje, um tsunami de imagens, de sons, símbolos e mercadorias diversas submerge o planeta inteiro, transformando a cada dia os nossos gostos, modos de viver, aspirações e sonhos, nossas opiniões sobre o mundo e nossa visão de que somos. Dessa extraordinária ebulição resultam realidades contraditórias. Um campo que ilustra bem essa contradição é a culinária: se é verdade que as redes de fast food invadem as cidades nos quatro cantos do mundo, é igualmente verdade que nessas mesmas cidades se encontra cada vez mais 
uma cozinha diversificada proveniente de vários países, não somente a italiana, francesa, indiana ou chinesa, que se exportavam há muito tempo, mas também a japonesa, a tailandesa, a indonésia, peruana, brasileira, mexicana, chilena, marroquina, libanesa, etc. Essa diversidade, a mesma que se observa também na música e no cinema, é um fenômeno revelador do que poderia significar uma globalização inclusiva.

Vale observar que a valorização das culturas alheias exclui todas as formas de apropriação pelas quais a cultura dominante toma como seus determinados elementos de uma outra cultura, um fenômeno que ocorre com mais frequência quando há interesses mercantis. Descartando a apropriação indevida, a diversidade é portadora de progresso e desenvolvimento em todos os campos de vida: nas artes em geral, na ecologia, no direito, nas instituições, nas formas de produzir e consumir, desde que os homens percebam a sua força criativa.

Quando os homens superam seus complexos e resolvem cooperar entre si, o outro será visto como parceiro e não adversário, e as animosidades se amenizam, instalando o princípio chave da reciprocidade. Hoje, todos se vêm levados a adotar inúmeros elementos que vêm das culturas hegemônicas do Ocidente, mas é essencial, para que não haja sentimento de exclusão, que cada um possa observar também que certos elementos da sua cultura (gastronomia, ritmos musicais, ritos, saberes, personagens, etc.) estão sendo adotados no mundo e fazem parte do patrimônio da humanidade. Dessa forma, ninguém mais se sentirá desvalorizado ao ponto de ser obrigado a dissimular aspectos de sua identidade, se odiar e odiar o mundo por isso.

$\mathrm{Na}$ relação de reciprocidade e respeito, os diferentes povos que se sentem marginalizados no mundo moderno podem passar a viver a modernidade e não a senti-la como fenômeno exógeno imposto. Nessa relação, abrem-se possibilidades para quebrar o círculo vicioso no qual se encontram aprisionados todos aqueles que se acham divididos entre a adesão à fé dos antigos e o desejo de universalização. Numa relação de integração igualitária, os muçulmanos podem vislumbrar a oportunidade de conciliar a cultura muçulmana com a cultura moderna e, consequentemente, curar a sua esquizofrenia. Fora disso, fica difícil parar o crescimento do número dos extraviados e impedir a formação de legiões de loucos sanguinários. Compreender e valorizar as culturas islâmicas é o meio mais poderosos de combater a violência dos fanáticos enfurecidos de Alá, solapar a difusão de suas ideias obscurantistas e minar a sua legitimação nos tecidos sociais.

Retrógrado, o radicalismo sunita deseja impor a lei muçulmana, a Sharia, tal como foi estabelecida na Suna, congelando qualquer tentativa de renovação. Fixar o dogma equivale a parar no tempo, o que vai de encontro ao mandamento do Ijtihad e condena o Islã ao declínio. Os extremistas têm como objetivo declarado a instauração de um regime teocrático anacrônico, no qual impõem aos correligionários uma conduta moral, 
cívica e religiosa, intrometendo-se na relação entre a criatura e o criador. Ora, na religião muçulmana, a relação entre o crente, o muslim, e Alá é direta, dispensa toda intermediação e qualquer imiscuidade ${ }^{12}$.

Os extremistas salafistas incitam à matança de todos que não aderem a seus dogmas, apresentando o ato como uma virtude que a fé em Alá exigiria, o que é anti-islâmico, uma vez que o Corão, no versículo 5:32, determina que: "quem mata um homem, mata toda humanidade". Interpretam o Jihad da maneira que melhor lhes convém para justificar suas atrocidades, explorando fora do contexto, trechos do Corão que supostamente apelam à violência. 0 significado do Jihad não é "guerra santa", mas, sim, o empenho do crente em permanecer na senda do bem sem vacilação (Lewis, 2005). Ainda, os textos sagrados do Islã não formam nenhum código jurídico e nem formulam injunções particulares. No momento da sua revelação, os versículos corânicos e o Hadith de caráter legislativo, correspondiam a necessidades flagrantemente circunstanciais e não podem ser aplicados ao pé da letra de forma universal ${ }^{13}$.

De qualquer modo, ser fiel aos preceitos da religião não é reproduzir as regras de vida das primeiras gerações de muçulmanos, mas, sim, buscar espiritualidade interior em vistas a reservar o culto a Deus, ao Alá, e não aos textos. Ser fiel de verdade é manter sua religiosidade estritamente no campo privado, de modo a preservá-la da gangue das interpretações que lhe obscurecem o sentido. Desembaraçada das ambições políticas dos fanáticos enfurecidos e de seus valores sectários, a mensagem de Maomé poderá voltar a ser o que nunca devia ter deixado de ser: um apelo à liberdade de consciência de quem nela crê.

\section{Considerações finais}

O Islã, como todas as religiões monoteístas, pode ser, em função do que dele se faz, um fator de alienação ou de auto alienação. Representa hoje uma plataforma hipotética para o radicalismo islâmico, mas também forma a última barreira contra as formas de imperialismo e de humilhação e frustração da maioria dos povos islâmicos, com diversos graus na expressão desses sentimentos e na instrumentalização da religião. Essa instrumentalização, frequentemente inconsciente, não é totalmente assumida pelos muçulmanos comuns e tampouco argumentada, porque no fundo eles sabem que não é remédio para seus males.

Em vez de se instalar no amargor e na resignação, alimentar o rancor e seus séquitos de desespero e violência suicida, em vez de continuar no confinamento e no

\footnotetext{
${ }^{12}$ Não existe confissão no Islã.

${ }^{13}$ A poligamia, por exemplo, se era possível naqueles tempos, era porque havia mais homens do que mulheres, em razão das guerras. Hoje, para ser possível, é necessário que haja um número de mulheres no mínimo duas a três vezes superior ao dos homens, senão a conta não fecha.
} 
declínio até desparecer na indiferença, as culturas de religião islâmica deveriam lutar para a sua sobrevivência, inscrevendo-se numa visão universal e modernista. Precisam ganhar aquela dupla batalha: em prol da universalidade dos valores e contra o unanimismo empobrecedor. Para isso, faz-se mister superar o dilema segundo o qual a modernização lhes implica necessariamente ficar à mercê da cultura ocidental e abrir mão da sua identidade. Esse dilema está deixando de ser pertinente, pois a modernidade hoje se tornou universal e não é mais privilégio exclusivo do Ocidente. Impõe-se para além das dimensões tecnológicas, que ainda estão comandadas pelo Ocidente. Está projetada nos valores de liberdade, democracia e justiça social, às quais aspiram todos os oprimidos.

Até mesmo no âmbito material, a própria tecnologia abre espaços extraordinários para a participação e a inserção cooperativa. A Internet é um grande exemplo de ferramenta integradora. Vista de fora e com desconfiança, representa um poderoso meio pelo qual as grandes potências estendem seus tentáculos sobre o planeta, mas, vista de dentro, é um formidável instrumento de liberdade, um espaço razoavelmente democrático no qual cada um, independentemente de suas origens, pode se envolver à vontade e, até mesmo, formar a opinião mundial, alcançar fortuna, fama e poder, se quiser. E, se na Web o inglês é predominante, a diversidade dos idiomas desabrocha cada vez mais, favorecida pelos programas de tradução corrente, que estão a ficar cada vez mais performantes.

Não obstante, o poder da vontade sozinho não pode conseguir o que se deseja, mas a história define-se pela práxis e, portanto, inclui o alvedrio humano. Quando a consciência dos povos alcançar o nível de desenvolvimento necessário para a mudança, as circunstâncias históricas que se encontrarão serão tais que não se alteram arbitrariamente. De qualquer modo, não se pode predeterminar, por inevitabilidade histórica, qual dentre os muitos possíveis desenvolvimentos tomará lugar. 


\section{Referências bibliográficas}

AGHA, Hussein \& MALLEY, R. The Arab Conterrevolution. The New York Review of Books, n. 21, 31 de Agosto de 2011.

AFRIQUE INSIDE. Irak: EIIL ou EI, l'Histoire d'une Ascension Meurtrière. Afrique Insisde: out., 2015. Disponível em: http://afriqueinside.com/irak-eiil-ei-lhistoire-dune-ascensionmeurtriere26082014/\#p4WYVOPkgMoMcxeK.99. Acesso: 12.09.2016.

AMGHAR, Samir. Le Salafisme d'Aujourd'hui et Mouvements Sectaires en Occident. Paris: Michalon, 2011.

ASHMAWY, Muhammad Sa'id Al. Against Islamic Extremism. Gainesville: University Press of Florida, 1998.

BASSIOUNI, M. Cherif. Islamic Civilization. Middle East Institut, Janeiro de 2012. Disponível em: http://www.mei.edu/content/islamic-civilization. Acesso: 23.04.2015.

BELAALI, Mohamed. Arabie Saoudite: le Silence Complice des Bourgeoisies Occidentales sur les Révoltes Populaires, março de 2012. Disponível em: http://www.belaali.com/articlearabie-saoudite-le-silence-complice-des-bourgeoisies-occidentales-sur-les-revoltespopulaires-109557989.html. Acesso: 23.04.2015.

BENJELLOUNE, Tahar. Le Califat Sauvage. Em: FOTTORINO, Eric. Qui Est Daech? Paris: Philippe Rey, 2015.

BLACK, Antony. The History of Islamic Political Thought: From the Prophet to the Present, Psychology Press, 2001. ISBN 978-0-415-93243-1. Acesso: 11.02.2013.

BURGAT, François. Djihadisme: Kepel et Roy Oublient l'essentiel. Une Troisième Voie Est Nécessaire. Paris: L'Obs, julho de 2016. Disponível em: http://leplus.nouvelobs.com/ contribution/1536258-djihadisme-kepel-et-roy-oublient-l-essentiel-une-troisieme-voieest-necessaire.html. Acesso: 21.10.2016.

CAILLET, Romain. From the Ba'th to the Caliphate: The Former Officers of Saddam and The Islamic State. The Norwegian Peacebuilding Resource Centre/Norsk Ressurssenter for Fredsbygging, v. 3. n. 36, junho de 2015.

CAMPANINI, Massimo. L'islamismo Jihadista a da Al-Qaeda All's. Analysis, n. 290, nov. 2015. Disponível em: http://www.ispionline.it/sites/default/files/pubblicazioni/analisi290_ campanini-16.11.2015.pdf. Acesso: 23.12.2016.

DAUMAS, Cécile. Olivier Roy et Gilles Kepel, Querelle Française sur le Jihadisme. Liberation, Paris, 14 de abril de 2016. Disponível em: http://www.liberation.fr/debats/2016/04/14/ olivier-roy-et-gilles-kepel-querelle-francaise-sur-le-jihadisme_1446226. Acesso: 23.11.2016.

DAWOD, Hosham. L'Etat Islâmique Est Trés Adapté à la Guerre Moderne. Em: FOTTORINO, Eric. Qui Est Daech? Paris: Philippe Rey, 2015 
FOUCHER Michel, Une Ambition Territoriale. Em: FOTTORINO, Eric. Qui Est Daech? Paris: Philippe Rey, 2015.

GIER, Nick. The Genocide of the Hazaras: Descendants of Genghis Khan Fight for Survival in Afghanistan and Pakistan, janeiro de 2016. Disponível em: http://sandpointreader.com/ the-genocide-of-the-hazaras/. Acesso: 08.07.2016.

GUIBERT, Nathalie. L'Etat Islamique, C'est 40000 Tweets en Français par Jour. Le Monde Paris: $\quad$ 01.06.2015.http://www.lemonde.fr/proche-orient/article/2015/06/01/l-etatislamique-compte-2-8-millions-de-francophones-sur-twitter_4645047_3218.html. Acesso: 10.12.2015.

HASHIMI, Al. Hisham. Daech, Son Organisation, Ses Financements, Son Armée, Ses Alliés Objectifs. Front de Gauche. Paris: fev., 2016. Disponível em: http://www.gauchemip.org/ spip.php?article25327. Acesso: 28.08.2016.

HERITAGE FOUNDATION, The. Isis Influence In Social Media. Web Vídeo. 04 de fevereiro de 2015. Disponível em: http://goo.gl/u2i5bD. Acesso: 02.07.2016.

IZERROUGENE, Bouzid. Argélia: a Tirania da Identidade e a Ascensão Fundamentalista. Afro.Ásia, 21-22, out. 1998.

KEPEL, Gilles. Jihad: Expansion et Déclin de l'Islamisme. Paris: Gallimard, 2000.

1993. . Le Prophète et le Pharaon: Aux Sources des Mouvements Islamistes. Paris: Seuil,

L' EXPRESS. Wahhabisme et Salafisme. L'Express. Paris: 22 de maio de 2003. Disponível em: http://www.lexpress.fr/informations/wahhabisme-et-salafisme_651719.html. Acesso: 21.01.2015.

LEWIS, Bernard. The Crisis of Islam: Holy War and Unholy Terror. N. York: Paperbacks, 2004

LOMBARDI, Laurent. Financement du Terrorisme: Ce Qu'il Est Possible de Dire du Rôle de l'Arabie Saoudite et du Qatar. Revue Atlantico: jan. 2015. Disponível em: http://www. atlantico.fr/decryptage/financement-terrorisme-que-sait-on-vraiment-role-arabiesaoudite-et-qatar-et-pourquoi-russie-peut-changer-donne-roland-lombardi-2453266. html. Acesso: 07.03.2015

MAALOUF, Amin. Les Identités Meurtrière. Paris: Grasset, 1998.

MARTINA, Giacomo. História da Igreja: de Lutero a Nossos Dias. 2.ed. São Paulo: Edições Loyola, 1996.

MABON, Simon. L'Arabie Saoudite, l'Iran et la Geopolitique Changeante de Moyen Orient. Afkar / Idées, 2016. Disponível em: http://www.iemed.org/observatori/arees-danalisi/ arxius-adjunts/afkar/afkar-46. Acesso: 03.07.2015.

MARTY, Martin E.; SCOTT R. Appleby. Fundamentalism and the State. Chicago: The University of Chicago Press, 1984. 
MILLS, Claire. Isis/Daesh: the Military Response in Iraq and Syria. Londres: House of Commons Library, 2016.

MIT POST ISIS, Promise of Paradise, Ticket to Hell. The Mit Post, dez. 2016. Disponível em: http://www.themitpost.com/far-paradise-ensnared-isis/. Acesso: 04.02.2017.

MONNIER, Vincent. L'Arabie Saoudite, Principal Bailleur de Fonds de Daech?. L'Obs. Paris: nov. 2016. Disponível em: http://tempsreel.nouvelobs.com/monde/20160119.0BS3021/ arabie-saoudite-le-principal-bailleurs-de-fonds-de-daech.html. Acesso: 02.02.2017.

MORIN, Edgar. Essayons de Comprendre. Em: FOTTORINO, Eric. Qui Est Daech? Paris: Philippe Rey, 2015.

PEW-FORUM. Mapping the Global Muslim Population. 2009. Disponível em: http://www. pewforum.org/files/2009/10/Muslimpopulation.pdf. Acesso: 23.03.2015.

PURI, Syed Shah M. Tazkarah Tul-Aikram Tarikh-e-Khulafa Arab-Wa-Islam. Kishwar: Kishwar Press, 1924.

ROY, Olivier. Um Islam Sans Racine ni Culture. Em: FOTTORINO, Eric. Qui Est Daech? Paris: Philippe Rey, 2015.

- Le Djihadisme Est Une Révolte Générationnelle et Nihiliste. Le Monde. Paris: 30/11/2015. Disponível em: http://www.lemonde.fr/proche-orient/ article/2015/06/01/l-etat-islamique-compte-2-8-millions-de-francophones-surtwitter_4645047_3218.html\#JV0hbqgcv2wJEzmb.99. Acesso: 12.12.2015.

SALEM, H. Nasser. Olhares Sobre as Revoltas no Mundo Árabe. Projeto História. São Paulo: n. 46, pp. 115-133, abr. 2013. Disponível em: revistas.pucsp.br/index.php/revph/article/ download/17133/13753. Acesso: 23.02.2015.

SHUSTER, Mike. Chronology: a History of the Shiite-Sunni Split. Fev. de 2007. Disponível em: http://www.npr.org/2007/02/12/7280905/chronology-a-history-of-the-shia-sunnisplit. Acesso: 23.02.2015.

SIGNIFICADOS. Dicionário On Line. 2016. Disponível em: https://www.significados.com. br/alteridade/. Acesso: 23.02.2015.

WEBER, Olivier. Le Fief de la Terreure. Em: FOTTORINO, Eric. Qui Est Daech? Paris: Philippe Rey, 2015.

ZELIN Y. Aaron. War Between ISIS and al-Qaeda for Supremacy of the Global Jihadist Movement. The Washington Institute, janeiro de 2014. Disponível em: http://www. washingtoninstitute.org/policy-analysis/view/the-war-between-isis-and-al-qaeda-forsupremacy-of-the-global-jihadist. Acesso: 23.07.2015. 